\title{
THE INFLUENCE OF DIFFERENT TYPES OF PHYSICAL ACTIVITY ON THE REDOX STATUS OF SCUBA DIVERS
}

Radmila Radojevic-Popovic ${ }^{1}$, Tamara Nikolic ${ }^{2}$, Isidora Stojic ${ }^{2}$, Jovana Jeremic ${ }^{2}$, Ivan Srejovic ${ }^{3}$, Goran Pesic ${ }^{4}$, Vladimir Jakovljevic ${ }^{3}$ ${ }^{1}$ Special Hospital for Hyperbaric Medicine, Belgrade, Serbia

${ }^{2}$ Department of Pharmacy, Faculty of Medical Sciences, University of Kragujevac, Kragujevac, Serbia ${ }^{3}$ Department of Physiology, Faculty of Medical Sciences, University of Kragujevac, Kragujevac, Serbia ${ }^{4}$ Orthopedic and Traumatology Clinic, Clinical Center Podgorica, Montenegro

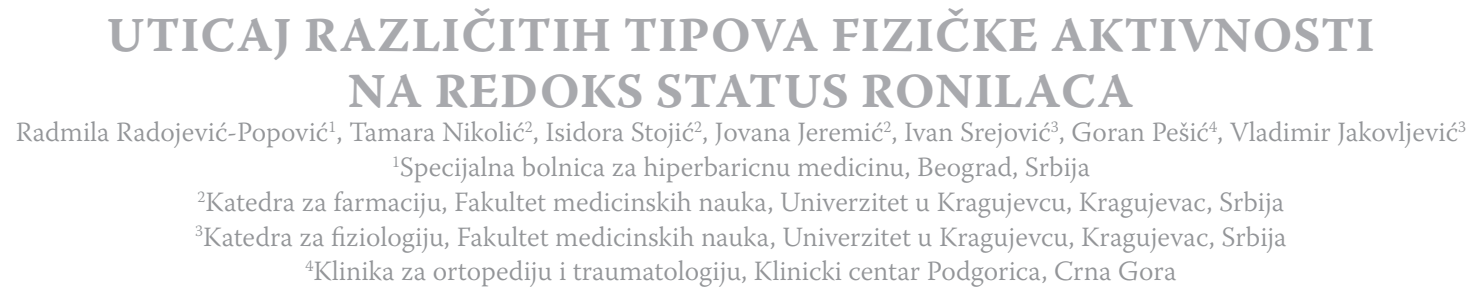

Received / Primljen: 05.07.2016.

Accepted / Prihvaćen: 19.07.2016.

\begin{abstract}
The effect of scuba diving on ROS production and oxidative stress compared to that of other recreational activities is still poorly understood. The aim of this study was to assess the influence of different types of physical activity on the redox status of scuba divers by testing the pro- and anti-oxidative parameters immediately before and after different types of physical load. The prevalence study included 10 professional police divers. All examinees were male, $32 \pm 5.1$ years of age, well-trained, and with a minimum of five to a maximum of 20 years of diving experience. The study was divided into three experimental protocols: 1) an exercise test (at atmospheric pressure), 2) an at sea dive (30 meters for 30 minutes), and 3) a dive into river current (10 meters for 30 minutes). Immediately before and after the load test of the divers at atmospheric pressure and immediately before and after the dive, blood samples were taken to determine the values of the following pro-oxidant markers: $\mathrm{O}_{2}^{-}, \mathrm{H}_{2} \mathrm{O}_{2} \mathrm{NO}_{2}^{-}$and TBARS, as well as antioxidant enzymes (SOD and CAT). A comparison of the results before and after physical activity for all three protocols revealed a significant increase in values for $\mathrm{NO}_{2}, \mathrm{O}_{2}, \mathrm{H}_{2} \mathrm{O}_{2}$ and CAT after physical activity. It can be concluded that the values of all oxidative stress markers depend on the season of the year in which the research is conducted or on the frequency of dives and degree of physical exertion during this period of the year.
\end{abstract}

Keywords: scuba diving, professional scuba divers, oxidative stress, free radicals

\section{SAŽETAK}

Efekti ronjenja na proizvodnju slobodnih radikala i oksidacioni stres su u odnosu na druge rekreativne sportive malo poznati. Ova studija je imala za cilj da ispita uticajrazličitih tipova fizičke aktivnosti na redoks status ronilaca putem merenja vrednosti pro- $i$ anti-oksidacionih parametara neposredno pre $i$ posle različitih vrsti napora. Studija prevalencije je obuhvatila 10 profesionalnih policijskih ronilaca. Svi ispitanici su bili muškarci, $32 \pm 5.1$ godina, dobro obučeni, sa ronilačkim iskustvom od najmanje pet do najviše 20 godina. Studija je bila podeljena u tri eksperimentalna protokola: 1. test opterećenja na ergo-biciklu (na atmosferskom pritisku), 2. zaron u moru (30 metara $u$ toku 30 minuta), $i$ 3. zaron u rečnoj struji (10 metara $u$ toku 30 minuta). Neposredno pre i posle testa opterećenja ili obe vrste zarona uzimani su uzorci krvi radi određivanja vrednosti pro-oksidanasa: $\mathrm{O}_{2}, \mathrm{H}_{2} \mathrm{O}_{2}, \mathrm{NO}_{2}^{-}$i TBARS, kao i enzima anti-oksidacione zaštite (SOD $i$ CAT). Poređenjem rezultata pre $i$ posle fizičke aktivnosti u sva tri protokola, pronadena je visoka statistička razlika u vrednostima $\mathrm{O}_{2}$, $\mathrm{H}_{2} \mathrm{O}_{2}, \mathrm{NO}_{2}-i$ CAT. Može se zaključiti da vrednosti svih markera oksidacionog stresa zavise od godišnjeg doba tokom kojeg je istraživanje sprovedeno ili od frekvencije ronjenja $i$ fizičke aktivnosti u ovom periodu godine.

Ključne reči: ronjenje, profesionalni ronioci, oksidacioni stres, slobodni radikali

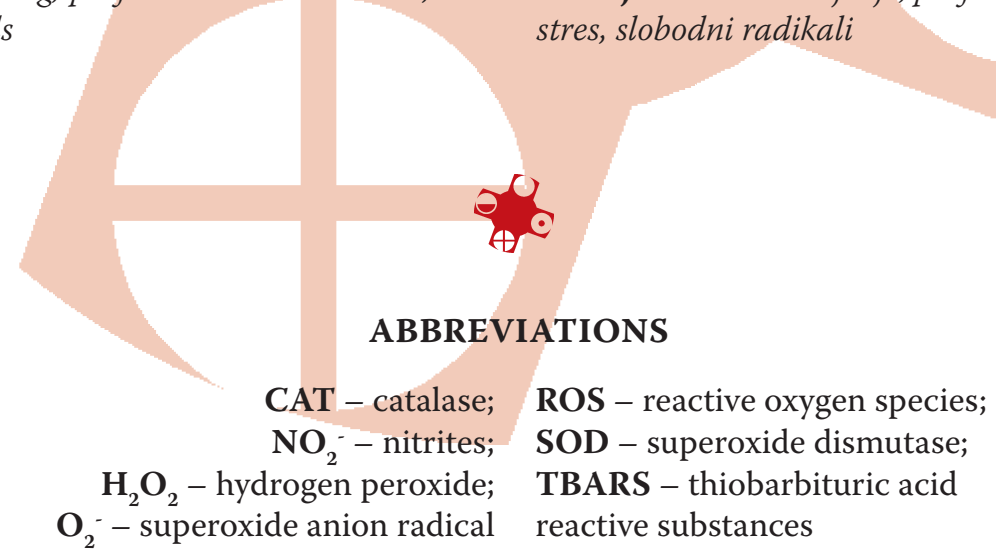




\section{INTRODUCTION}

An imbalance between free radical production and antioxidant defence in the human body leads to an oxidative stress state. The negative effects of oxidative stress are associated with the pathophysiology of many diseases and aging. These effects are the consequence of a reduction in resistance to oxidative stress with aging and the accumulation of free radicals. Although it is well known that physical exercise can increase oxidative stress and cause disruption of redox homeostasis (1-4), many studies have shown a beneficial role of the reactive oxygen species (ROS) produced during exercise, which leads to important training adaptations, including an increase in resistance to oxidative stress, angiogenesis, mitochondria biogenesis, and muscle hypertrophy (1).

It is well established that exercise can have both positive and negative effects on oxidative status depending on the exercise load, exercise specificity and the basal physical condition level. However, the effect of scuba diving on ROS production and oxidative stress resistance compared to other recreational activities is still unknown. Furthermore, it remains unclear in which circumstances the practice of scuba diving can be helpful or harmful (5).

Due to the weight of the diving equipment and increased resistance to movement, scuba diving is a demanding physical activity. Furthermore, divers are exposed to changes in environmental conditions that are not usually present in other types of physical activity. In addition to underwater pressure and cold temperatures, these changes include breathing oxygen at an elevated pressure and increased resistance to breathing (6). Intensified physical activity and coldness can lead to the increased production of free radicals. Additionally, hyperoxia as a result of hyperbaric exposure during diving and breathing oxygen at a high pressure could induce oxidative stress (7).

The current data on the influences of scuba diving on oxidative status are controversial; while some studies describe positive effects, other studies suggest undesirable consequences of scuba diving on human health. The main reason for such ambiguous results is that the studies were conducted under different conditions, including differences in the selection of evaluated biomarkers of oxidative status and the time and method of determination (5).

On the basis of the information stated previously, the aim of this study was to assess the influence of different types of physical activity on the redox status of scuba divers.

\section{MATERIALS AND METHODS}

\section{Study population}

This study included 10 professional police divers who were participating in the training process, which included dive training at the sea and at a river. All examinees were male, $32 \pm 5.1$ years of age, well-trained, and with a mini- mum of five to a maximum of 20 years of diving experience. During their diving service, participants were subjected to regular annual medical check-ups by a specialist. During this study, divers had no signs of any acute or chronic disease. They had valid medical documentation that proved they were able to perform the duties of professional divers.

Four weeks prior to blood sampling, the divers were instructed to refrain from any vitamin or antioxidant dietary supplementation. None of the participants reported any eating disorders, had any ongoing or previous injuries (during the last six months), and were not on any medications known to affect oxidative stress. To exclude the influence of different dietary intakes on nitrite levels, all participants were on the same dietary protocol for three days before the study and during the study. This protocol consisted of a prescribed menu for police divers.

All subjects were non-smokers and had normal values of arterial blood pressure, normal echocardiogram, ECG, EEG, and spirometry results, and normal values of fat and sugar in the blood. All divers received an explanation of the study's purposes, risks and benefits and were familiarized with the study's protocol. All subjects gave written consent. The study was approved by the Ethical Committee of the Faculty of Medical Sciences, University of Kragujevac.

\section{Design of the study}

The study was divided into three experimental protocols:

1) For the first testing protocol, the parameters of oxidative stress and the antioxidant protection components were determined immediately before and after theload test of the divers at atmospheric pressure. Before the load test, an ECG was performed on each diver. The workload test entailed progressively increasing the workload during a continuous test on a training bike (8). Maximal oxygen uptake $\left(\mathrm{VO}_{2} \max \right)$ was measured by a direct method with the help of the $\mathrm{Fi}^{\circ}$ Pro apparatus (Cosmed, Italy) (9). Heart rate was measured using a heart rate monitor belt (HR Polar S810, Finland). Assessment of body composition was performed using the bioimpedance method with the machine In Body 720 (Biospace, Korea).

2) Diving protocol 1: Testing was performed at the seaside during a dive training of professional police divers held in May. All divers were dressed in neoprene drysuits and were equipped with open-circuit scuba diving apparatus. The primary cylinders were 18-litre bottles filled with compressed air with an average pressure of 205 bars. The morning medical examination was conducted before the dive and included auscultatory findings from the lungs and measurements of blood pressure and pulse. After arriving at the location, each diving pair made a dive to the specified depth. Each set of divers launched every five minutes. The specified depth was 30 meters and was controlled with either a Suunto or Mares dive computer. The specified duration of the 
dive was 30 minutes. During the dive, the divers were instructed to moderate their loads. The descent was at 10 meters/minute, and the ascent was 9 meters/minute, with a three-minute decompression/safety stop at a depth of 3 meters. All 10 divers completed the dive successfully without any sign of decompression sickness. The average air consumption was 56 litres (L) per minute. Air temperature during the examination was $23^{\circ} \mathrm{C}$, and sea temperature was $15^{\circ} \mathrm{C}$ to $19^{\circ} \mathrm{C}$.

3) Diving protocol 2: Testing was performed in river currents during a dive training of professional police divers held in May and in November. All divers were dressed in neoprene drysuits and were equipped with opencircuit scuba diving apparatus. The primary cylinders were 18-litre bottles filled with compressed air with an average pressure of 195 bars. The morning medical examination was conducted before the dive and included auscultatory findings from the lungs and measurements of blood pressure and pulse. After arriving at the location, each diver made a dive to the specified depth. The specified depth was 10 meters and was controlled with either a Suunto or Galileo Sol dive computer, which measured the amount of air inhaled and the pulse of the divers. The specified duration of the dive was $30 \mathrm{~min}$ utes. During the boat ride to the location of the river current, divers simulated a search of the terrain using the pendulum method. The scuba diver with a life rope tied to the dive boat was a reserve diver. The descent was at 10 meters/minute, and the ascent was 9 meters/ minute. All 10 divers completed the dive successfully. The average air consumption was 22 litres (L) per minute. Air temperature during the examination was $23^{\circ} \mathrm{C}$, and the river temperature was $12^{\circ} \mathrm{C}$ to $18^{\circ} \mathrm{C}$.

\section{Sample collection protocol}

Immediately before and after the load test at atmospheric pressure and immediately before and after the dive, blood samples were taken from the divers to determine levels of the following pro-oxidant markers: superoxide anion radical $\left(\mathrm{O}_{2}^{-}\right),\left(\mathrm{H}_{2} \mathrm{O}_{2}\right)$, nitrites $\left(\mathrm{NO}_{2}^{-}\right)$and the index of lipid peroxidation (TBARS), as well as the activity of antioxidant enzymes (SOD and CAT). Four weeks prior to blood sampling, the divers were instructed to refrain from any vitamin or antioxidant dietary supplementation. None of the participants reported any eating disorders, had any ongoing or previous injuries (during the last six months), and were not on any medications known to affect oxidative stress. To exclude the influence of different dietary intakes on nitrite levels, all participants were on the same dietary protocol for three days before the study and during the study.

\section{Biochemical assays}

Blood samples were drawn from the antecubital vein of each diver into Vacutainer test tubes containing sodium citrate anticoagulant. Blood samples were processed and stored immediately. The blood was centrifuged to separate the plasma and red blood cells (RBCs). Biochemical parameters were measured spectrophotometrically.

\section{Index of lipid peroxidation (thiobarbituric acid reactive substances, TBARS) determination}

The degree of lipid peroxidation in plasma was estimated by measuring TBARS using $1 \%$ TBA (thiobarbituric acid) in $0.05 \mathrm{NaOH}$ that was incubated with plasma at $100^{\circ} \mathrm{C}$ for $15 \mathrm{~min}$ and read at $530 \mathrm{~nm}$. Distilled water was used as a blank probe. TBA extract was obtained by combining $0.8 \mathrm{ml}$ plasma and $0.4 \mathrm{ml} \mathrm{TCA}$ (trichloroacetic acid). Samples were put on ice for $10 \mathrm{~min}$ and centrifuged for $15 \mathrm{~min}$ at $6000 \mathrm{rpm}$. This method was described previously (10).

\section{Nitrites $\left(\mathrm{NO}_{2}^{-}\right)$determination}

NO decomposes rapidly to form stable metabolite nitrite/nitrate products. $\mathrm{NO}_{2}{ }^{-}$was determined as an index of nitric oxide production using the Griess reagent (11). 0.1 $\mathrm{ml} 3 \mathrm{~N}$ PCA (perchloride acid), $0.4 \mathrm{ml} 20 \mathrm{mM}$ EDTA (ethylenediaminetetraacetic acid) and $0.2 \mathrm{ml}$ plasma were put on ice for $15 \mathrm{~min}$ and then centrifuged for $15 \mathrm{~min}$ at 6000 $\mathrm{rpm}$. After pouring off the supernatant, $220 \mu \mathrm{K} \mathrm{K}_{2} \mathrm{CO}_{3}$ was added. $\mathrm{NO}_{2}^{-}$was measured at $550 \mathrm{~nm}$. Distilled water was used as a blank probe.

\section{Superoxide anion radical $\left(\mathrm{O}_{2}^{-}\right)$determination}

The level of $\mathrm{O}_{2}$ - was measured using an NBT (nitro blue tetrazolium) reaction in TRIS-buffer combined with plasma samples and read at $530 \mathrm{~nm}$ (12).

\section{Hydrogen peroxide $\left(\mathrm{H}_{2} \mathrm{O}_{2}\right)$ determination}

The protocol for the measurement of $\mathrm{H}_{2} \mathrm{O}_{2}$ is based on the oxidation of phenol red in the presence of horseradish peroxidase (13). Two hundred microlitres of plasma with $800 \mu \mathrm{l}$ PRS (Phenol Red Solution) and $10 \mu \mathrm{l}$ POD (Horseradish Peroxidase) were combined (1:20). The level of $\mathrm{H}_{2} \mathrm{O}_{2}$ was measured at $610 \mathrm{~nm}$.

\section{Determination of the activities of antioxidant enzymes}

Isolated RBCs were washed three times with three volumes of ice-cold $0.9 \mathrm{mmol} / \mathrm{l} \mathrm{NaCl}$, and hemolysates containing approximately $50 \mathrm{~g} \mathrm{Hb} / \mathrm{l}$ (14) were used for the determination of CAT activity. CAT activity was determined according to the methods described by Beutler (15). Lysates were diluted with distilled water $(1: 7 \mathrm{v} / \mathrm{v})$ and treated with chloroform-ethanol $(0.6: 1 \mathrm{v} / \mathrm{v})$ to remove haemoglobin (16). Subsequently, $50 \mu \mathrm{l}$ CAT buffer, $100 \mu \mathrm{l}$ sample and $1 \mathrm{ml} 10 \mathrm{mM} \mathrm{H}_{2} \mathrm{O}_{2}$ were added to the samples. Detection was performed at $360 \mathrm{~nm}$. Distilled water was 
used as a blank probe. SOD activity was determined by the epinephrine method of Misra and Fridovich (17). A mixture of $100 \mu \mathrm{l}$ lysate and $1 \mathrm{ml}$ carbonate buffer was made, following which $100 \mu \mathrm{l}$ of epinephrine was added. Detection was performed at $470 \mathrm{~nm}$.

\section{Statistical analysis}

The statistical analysis was performed using SPSS 19.0 for Windows. The results are expressed as the means \pm standard deviation of the means (SD). Data distribution was checked with the Shapiro-Wilk test and depending on its results, the appropriate parametric or non-parametric test was used. The differences between the values of the means from two related samples (before and after the dive) were assessed by Wilcoxon's test, while the difference between two unrelated samples (characteristics of the exercise protocol) was assessed by Student's t-test.

The alpha level for significance was set to $\mathrm{p}<0.05$.

\section{RESULTS}

All subjects participating in the first protocol had normal ECG findings, while the average value of $\mathrm{VO}_{2} \max$ was $42.4 \mathrm{l} / \mathrm{kg}$. The results of aerobic capacity were marked as excellent in 1 subject, very good in 5 subjects and good in 4 subjects. The average air consumption was $133.6 \mathrm{l} / \mathrm{min}$.

\section{The effects of different types of physical activity on TBARS concentration}

No significant differences in the TBARS values before or after physical activity were observed among any of the three protocols (groups) ( $p>0.05)$. TBARS dynamics were also unchanged before and after physical loading within all of the protocol groups $(\mathrm{p}>0.05)$.

\section{The effects of different types of physical activity} on $\mathrm{NO}_{2}^{-}$concentration

Before physical activity, $\mathrm{NO}_{2}$ - values were significantly higher in the exercise test group compared to sea and river dive groups $(p<0.01)$. After physical loading, values were the highest in the sea dive group and lowest in the river dive group $(\mathrm{p}<0.01)$. When comparing $\mathrm{NO}_{2}{ }^{-}$values within each protocol group, this marker was increased in the sea dive protocol group $(\mathrm{p}<0.01)$, and no significant change in $\mathrm{NO}_{2}^{-}$was noted in the exercise test and river dive protocol groups ( $\mathrm{p}>0.05$ ).

\section{The effects of different types of physical activity}

on $\mathrm{O}_{2}^{-}$concentration

Before physical activity, $\mathrm{O}_{2}^{-}$values were significantly higher in the river dive group compared to the sea dive and exercise test groups $(\mathrm{p}<0.01)$. After physical loading, values were the highest in the sea dive group and the lowest in the exercise test group $(\mathrm{p}<0.01)$. When comparing $\mathrm{O}_{2}$ values within each protocol (group), we observed that this parameter was decreased after physical effort in the river dive protocol group $(\mathrm{p}<0.05)$, increased in the sea dive group $(\mathrm{p}<0.05)$, and remained unchanged in the exercise test protocol group ( $\mathrm{p}>0.05)$.

\section{The effects of different types of physical activity} on $\mathrm{H}_{2} \mathrm{O}_{2}$ concentration

The values of $\mathrm{H}_{2} \mathrm{O}_{2}$ were significantly higher in the sea dive group compared to the river dive and exercise test groups, both before and after physical activity $(\mathrm{p}<0.01)$. When comparing $\mathrm{H}_{2} \mathrm{O}_{2}$ values within each protocol (group), this marker was increased after physical loading in the sea dive protocol group ( $\mathrm{p}<0.05)$, but no significant change in $\mathrm{H}_{2} \mathrm{O}_{2}$ was observed in the river dive and exercise test protocol groups $(\mathrm{p}>0.05)$.

\section{The effects of different types of physical activity on CAT values}

The CAT values were significantly higher in the exercise test protocol group compared to the sea dive $(\mathrm{p}<0.05)$ and river dive protocol groups, $(\mathrm{p}<0.01)$ both before and after physical activity. Values of this enzyme were unchanged before and after physical loading in all of the protocol groups $(\mathrm{p}>0.05)$.

\section{The effects of different types of physical activity on $S O D$ values}

In contrast to the previous results, SOD values after physical activity were significantly higher in the river and exercise test protocol groups compared to the sea dive group $(\mathrm{p}<0.01)$. Furthermore, significant differences were not observed between the exercise test and river dive protocol groups ( $p>0.05$ ). Values of this enzyme remained unchanged before and after physical effort in all of the protocol groups $(\mathrm{p}>0.05)$.

\section{DISCUSSION}

It is well established that exercise can have both positive and negative effects on oxidative status depending on exercise load, exercise specificity and the basal physical condition level. However, compared to other sport activities, data referring to the effect of scuba diving on redox status are insufficient. Furthermore, it remains unclear in which circumstances scuba diving can be helpful or harmful (5). Therefore, the aim of the present investigation was to assess the influence of different types of physical activity on the redox status of scuba divers.

In our study, the first protocol required the divers to participate in a stress test on a training bike at atmospheric pressure. In the second protocol, the divers performed diving under the sea at 30 meters for 30 minutes. Because of the weight of the diving equipment and an increased resistance to movement, the dive was considered to be a very demanding physical activity. In the third protocol, the divers participated in shallow diving (up to 10 meters) in 
river currents, in which a diver experiences a physical load in the form of the resistance of the river current.

While in the water current, a diver's body cools faster and thus increases power consumption, which reduces the working capacity of the divers. Reduced visibility decreases the diver's orientation and timely response. The power consumption in the diver during the activity is expected to increase most of the pro-oxidative parameters and reduce antioxidant protection.

It is important to emphasize that the research involving the second protocol was conducted between May and June during regular training at the sea, which occurred after the winter break in training dives. The first protocol was conducted during June and July after returning from the diving training at the sea. Finally, after returning from regular training at the sea, the research involving the third protocol was conducted, which consisted of diving in river currents, during the period from October to mid-November of the same year.

The comparison of the TBARS results before and after physical activity in all three protocols showed no statistically significant differences (Fig. 1). The most likely explanation for this finding is that divers were individually well-trained and developed strong antioxidant systems that did not allow the occurrence of lipid degradation. the In contrast, highly significant differences were observed in the values of other pro-oxidant markers, namely, $\mathrm{NO}_{2}, \mathrm{O}_{2}$ and $\mathrm{H}_{2} \mathrm{O}_{2}$. These results are most likely the consequence of external factors such as training frequency, dive frequency, diet, and the period during which the research was conducted.

When comparing the results before and after physical activity in each protocol, we observed that $\mathrm{NO}_{2}$ - release increased after the sea dive, remained unchanged in the river dive and decreased during the stress exercise test (Fig. 2). These findings most likely resulted from the physical activity that was performed in the course of these protocols. Moreover, considering the research period for these protocols, the values of $\mathrm{NO}_{2}^{-}$may be the result of adaptation of the organism due to the frequent number of dives made during regular training at the sea and during the diving training in inland waters.

The difference in $\mathrm{O}_{2}^{-}$release both before and after physical activity in all three protocols was statistically significant. This finding may indicate that various types of exercise have different influences on the formation of $\mathrm{O}_{2}$ The lowest values of $\mathrm{O}_{2}^{-}$were found before the effort and at the end of the season of frequent dives, which indicates a possible adaptation to increased $\mathrm{O}_{2}^{-}$release. However, these results should be considered with caution, considering the short half-life and high reactivity of $\mathrm{O}_{2}^{-}(18)$.

When comparing the values of this parameter for each protocol, an increase in the $\mathrm{O}_{2}$ - production was observed during a sea dive to 30 meters for 30 minutes, but a reduction in its release was observed during a river dive (Fig. 3). This finding is probably caused by the lower depth of the dive in the river compared to the sea dive. We have at-

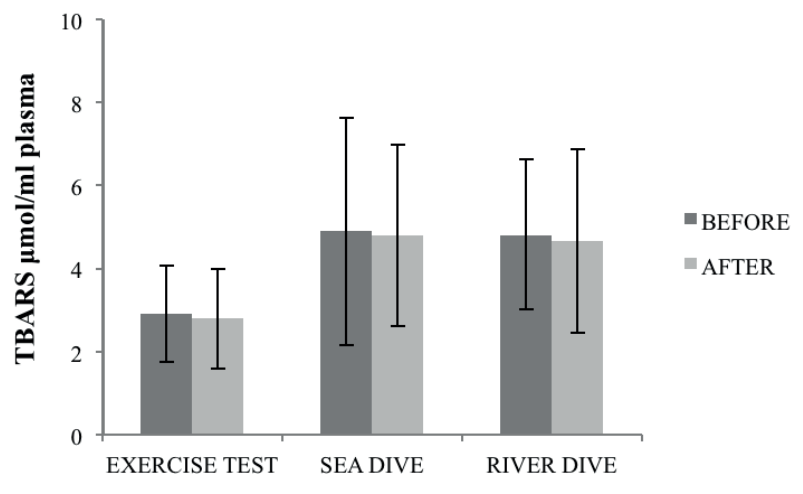

Figure 1. TBARS values before and after physical activity in all three protocols $\mathrm{P}$ values less than 0.05 were considered to be significant $\left({ }^{*} \mathrm{p}<0.05\right.$; *** $\mathrm{p}<0.01)$.

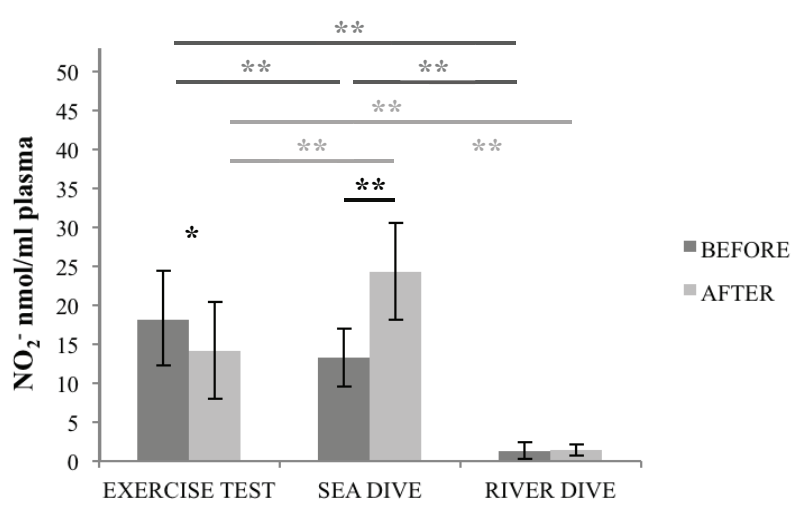

Figure 2. $\mathrm{NO}_{2}$ - values before and after physical activity in all three protocols. $\mathrm{P}$ values less than 0.05 were considered to be significant $($ " $\mathrm{p}<0.05$; $*$ p $<0.01)$.

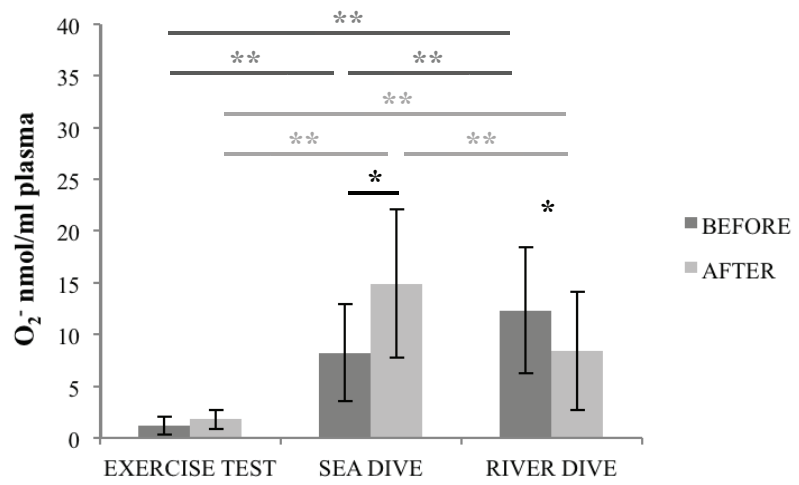

Figure 3. $\mathrm{O}_{2}^{-}$values before and after physical activity in all three protocols. $\mathrm{P}$ values less than 0.05 were considered to be significant (" $\mathrm{p}<0.05$ **: $\mathrm{p}<0.01)$.

tempted to compare our results with data from the available literature, but unfortunately, we did not find any related studies published in this field.

The values of the results for the $\mathrm{H}_{2} \mathrm{O}_{2}$ showed highly significant differences in all three protocols before and after exercise (Fig. 4). Similar to previous cases, the above mentioned external factors were likely to have an impact 


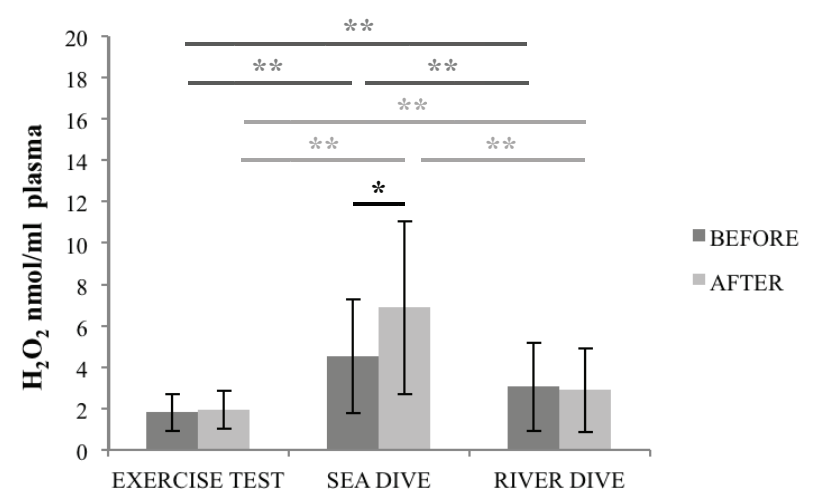

Figure 4. $\mathrm{H}_{2} \mathrm{O}_{2}$ values before and after physical activity in all three protocols. $P$ values less than 0.05 were considered to be significant (" $\mathrm{p}<0.05$ $\left.{ }^{* *} \mathrm{p}<0.01\right)$.

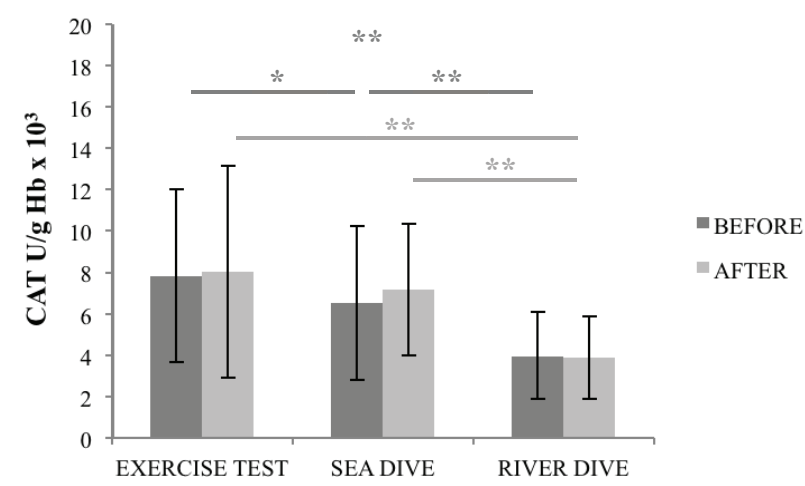

Figure 5. CAT values before and after physical activity in all three protocols. $\mathrm{P}$ values less than 0.05 were considered to be significant (" $\mathrm{p}<0.05$; *** $\mathrm{p}<0.01)$.

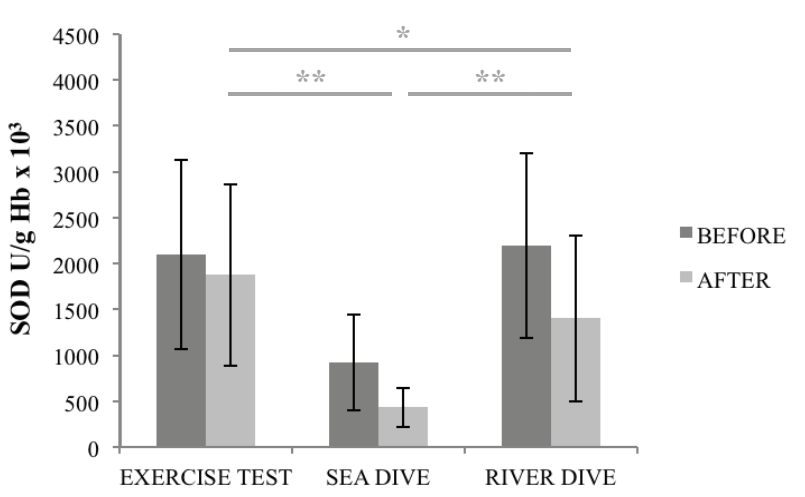

Figure 6. SOD values before and after physical activity in all three protocols $\mathrm{P}$ values less than 0.05 were considered to be significant $\left({ }^{*} \mathrm{p}<0.05\right.$; ** $\mathrm{p}<0.01)$.

on these results. The $\mathrm{H}_{2} \mathrm{O}_{2}$ release increased during the sea dive, while they remained unchanged over the course of a dive in the river current and during the stress test. This result could be a consequence of the greater depth of the sea dive and easier adaptation to physical effort in the river stream and during the stress test.
Moreover, it may be expected that during a dive, the functioning of the antioxidative enzymatic system should change. Thus, we investigated the activity of two major antioxidative enzymes, CAT and SOD, to create the most complete picture of each diver's redox state. SOD catalyses the dismutation of $\mathrm{O}_{2}^{-}$to $\mathrm{H}_{2} \mathrm{O}_{2}$ and allows for better interpretation of results regarding $\mathrm{O}_{2}^{-}$and $\mathrm{H}_{2} \mathrm{O}_{2}$ (19), while CAT decomposes $\mathrm{H}_{2} \mathrm{O}_{2}$ to $\mathrm{H}_{2} \mathrm{O}$ and $\mathrm{O}_{2}(19)$.

The results for CAT showed highly significant differences in all three protocols before and after exercise, suggesting that external factors are likely to have an impact on the results.

Comparing the results before physical activity in all three protocols, no significant differences in the values of SOD were observed. However, by contrast, when we compared the results after the physical stress loads were applied in all three protocols, highly significant differences in the activity of this enzyme were observed.

If we observe the time period when the research was conducted and the values of SOD, higher values were measured during the first protocol (training at the sea from May to June) and the third protocol (training at the sea in September and October). The increased SOD values in the divers during these training periods seem to be related to a long period of exposure to increased physical effort. The increased SOD values most likely increased the ability of the diver's body to endure the oxidative stress, which in this case could have been caused by different types of physical activities such as sea diving to 30 feet for 30 minutes, diving in the river current and participating in a stress test at atmospheric pressure.

\section{CONCLUSION}

Considering that our study involved professional divers who all had several years of diving experience, it can be assumed that due to frequent dives, a variety of diving training methods and well-trained endurance to physical stress, a well-adapted antioxidant protection system already existed in the divers. We can conclude that diving in the sea caused the greatest oxidative damage, which is followed by the weakest antioxidant response. Analysing the results of markers of oxidative stress and antioxidant protection, it can be concluded that values of pro- and anti-oxidants depend on the season of the year in which the research is conducted or on the dive frequency and degree of physical exertion during this period of time.

\section{REFERENCES}

1. Gomes EC, Silva AN, de Oliveira MR. (2012). Oxidants, antioxidants, and the beneficial roles of exerciseinduced production of reactive species. Oxid Med Cell Longev. 2012:756132. 
2. Ashton T, Young IS, Peters JR, Jones E, Jackson SK, Davies B, Rowlands CC. (1985). Electron spin resonance spectroscopy, exercise, and oxidative stress: an ascorbic acid intervention study. J Appl Physiol. 87(6):20322036.

3. Bailey DM, Young IS, McEneny J, Lawrenson L, Kim J, Barden J, Richardson RS. (2004). Regulation of free radical outflow from an isolated muscle bed in exercising humans. Am J Physiol Heart Circ Physiol. 287(4):H1689-1699.

4. Bailey DM, Lawrenson L, McEneny J, Young IS, James PE, Jackson SK, Henry RR, Mathieu-Costello O, McCord JM, Richardson RS. (2007). Electron paramagnetic spectroscopic evidence of exercise-induced free radical accumulation in human skeletal muscle. Free Radic Res. 41(2):182-190.

5. Perovic A, Unic A, Dumic J. (2014). Recreational scuba diving: negative or positive effects of oxidative and cardiovascular stress? Biochem Med (Zagreb). 24(2):235-247.

6. Doubt, TJ. (1996). Cardiovascular and thermal responses to SCUBA diving. Med Sci Sports Exerc. 28:5816.

7. Ferrer MD, Sureda A, Batle JM, Tauler P, Tur JA, Pons A. (2007). Scuba diving enhances endogenous antioxidant defenses in lymphocytes and neutrophils. Free Radic Res. 41:274-281.

8. Cabo JV, Martinez-Camblor P, Del Valle M. (2011). Validity of the modified conconi test for determining ventilatory threshold during on-water rowing. J Sports Sci Med. 10(4):616-623.

9. Brisswalter J, Tartaruga MP. (2014). Comparison of COSMED'S FitMate $^{\mathrm{Tw}}$ and K4b2 metabolic systems reliability during graded cycling exercise. Scand J Clin Lab Invest. 74(8):722-724.
10. Ohkawa H, Ohishi N, Yagi K. (1979). Assay for lipid peroxides in animal tissues by thiobarbituric acid reaction. Anal Biochem. 95:351-358.

11. Green LC, Wagner DA, Glogowski J, Skipper PI, Wishnok JS, Tannenbaum SR. (1982)- Analysis of nitrate, nitrite and $[15 \mathrm{~N}]$ nitrate in biological fluids. Anal Biochem. 126:131-138.

12. Auclair, C., Voisin E. (1999). Nitroblue tetrazolium reduction. In: R.A. Greenwald (Ed.), Handbook of methods for oxygen radical research (pp. 123-132). Boka Raton: CRC Press, Inc.

13. Pick E, Keisari Y. (1980). A simple colorimetric method for the measurement of hydrogen peroxide produced by cells in culture. J Immunol Methods. 38(1-2):161-170.

14. McCord JM, Fridovich I. (1969). Superoxide dismutase. An enzymic function for erythrocuprein (hemocuprein). J Biol Chem. 244(22):6049-6055.

15. Beutler, E. (1982). Catalase. In: E. Beutler (Ed.), Red cell metabolism, a manual of biochemical methods (pp. 105-106). New York: Grune and Stratton.

16. Tsuchihashi M. (1923). Zur Kernntnis der blutkatalase. Biochem Zeits. 140:65-72.

17. Misra HP, Fridovich I. (1972). The role of superoxide-anion in the autooxidation ofepinephrine and a simple assay for superoxide dismutase. J Biol Chem. 247:3170-3175.

18. Radojevic-Popovic R, Zivkovic V, Jeremic N, Sretenovic J, Velicanin N, Bradic J, Jakovljevic V. (2015). An evaluation of the redox state in professional scuba divers. Undersea Hyperb Med. 42(5):409-416.

19. Giorgio M, Trinei M, Migliaccio E, Pelicci PG. (2014). Hydrogen peroxide: a metabolic by-product or a common mediator of ageing signals? Nat Rev Mol Cell Biol. 15:786-801. 


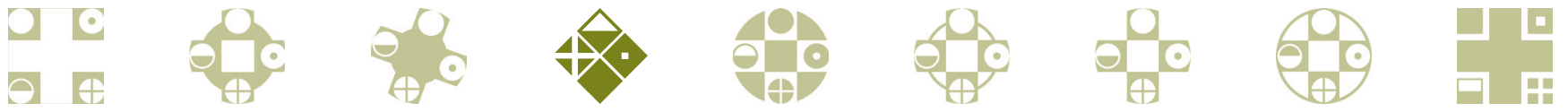

